\title{
Assessment of Pearl Millet Genotypes for Downy Mildew Resistance and Agronomic Performance under Field Conditions in Senegal
}

\author{
Yedomon Ange Bovys Zoclanclounon ${ }^{1 *}$, Ghislain Kanfany ${ }^{1,2}$, Cheikh Thiaw ${ }^{3}$, Amadou Fofana ${ }^{3}$, Nalla Mbaye ${ }^{4}$ and \\ Ndiaga Cisse ${ }^{1}$ \\ ${ }^{1}$ Centre d'Etudes Régional pour l'Amélioration de l'Adaptation à la Sécheresse, BP 3320, Route de Khombole, Thiès, Sénégal \\ ${ }^{2}$ West Africa Center for Crop Improvement, University of Ghana, PMB 30, Accra, Ghana \\ ${ }^{3}$ Centre National de Recherches Agronomiques de Bambey, Institut Sénégalais de Recherches Agricoles, BP 211 Bambey, \\ Sénégal \\ ${ }^{4}$ Faculté des Sciences et Techniques, Université Cheikh Anta Diop de Dakar, BP 5005 Fann-Dakar, Sénégal \\ *For correspondence: angez9914@gmail.com
}

\begin{abstract}
Sclerospora graminicola is a pathogen that causes important damage in pearl millet [Pennisetum glaucum (L.) R. Brown] fields in Asia and Africa. In order to identify new sources of resistance to this disease, a set of 20 genotypes was assessed during the rainy season 2015 at Bambey, Nioro, Kolda and Sinthiou Maleme research stations in Senegal. Comparative survey between locations showed that the highest downy mildew incidence (100\%) was recorded in Kolda. The 7042S, an international susceptible check, showed downy mildew incidence of $91.12 \%$, IP22441 line was susceptible at Kolda (incidence $=30.5 \%$ ), resistant at Sinthiou Maleme (incidence $=6.5 \%$ ), moderately resistant at Bambey (incidence $=18 \%$ ) and highly susceptible at Nioro (incidence $=70 \%$ ). IP22295 line was susceptible at Kolda (incidence $=24.5 \%$ ) but resistant at Bambey (incidence $=0 \%$ ), Nioro (incidence $=3.5 \%$ ) and Sinthiou Maleme (incidence $=0 \%$ ). A hierarchical cluster analysis of these tested genotypes integrating agronomic parameters and response to downy mildew has identified four genotype groups characterized by downy mildew resistance, vegetative growth, panicle yield and flowering time. This study has shown the variability of S. graminicola populations from different tested locations. Genotypes IP22315, IP2295, SOSAT-C88-Sadore and SOSAT-C88-Pantacheru presented stable resistance to downy mildew across the tested locations. These genotypes can be used as parents for breeding pearl millet varieties resistant to the downy mildew disease under Senegal environments. (C) 2018 Friends Science Publishers
\end{abstract}

Keywords: Downy mildew; Incidence; Pearl millet; Resistance; Senegal

\section{Introduction}

Pearl millet [Pennisetum glaucum (L.) R. Br.] is an important crop grown in Asia and Africa. It is a vital staple food crop for poor people in dry-land areas (Das, 2017). Climate change resilience, soil salinity and acidity tolerance are key characteristics of this crop in sustaining food security, nutrition and health in dry-land zones (Jukanti et al., 2016). Approximately, 500 million people depend on pearl millet and it is currently grown on 28 million hectares throughout the world (Siddaiah et al., 2017). In Senegal, this cereal is the most cultivated with approximately 922,008 hectares as harvested area and 749,874 tons produced in 2015 (Diagne et al., 2017). Diourbel, Fatick, Kaolack, Kaffrine, Kolda and Tambacounda are the main pearl millet production regions in Senegal.

One of the major biotic constraints of pearl millet production is downy mildew disease (Sharma et al., 2011). It is caused by an oomycete, Sclerospora graminicola, a very destructive pathogen that can cause $80 \%$ yield loss (Sudisha et al., 2011). Because of its genetic (Sastry et al., 1995) and pathogenic variability (Pushpavathi et al., 2006; Sudisha et al., 2009), identification and monitoring of new sources of resistance are important in downy mildew management.

Several studies highlighted some host specific resistance (Hash et al., 2006; Sharma et al., 2011). But assessment of genotypes with interesting agronomic characteristic including resistance to downy mildew in Senegal field conditions is not clearly established. In addition, it is a great challenge to maintain durable stability in plant breeding when pathogen populations' variability risk exists (Leonard, 1977; Dangl and Jones, 2001). In fact, characterization of potential S. graminicola populations' virulence is currently unknown in Senegal. A multi-location monitoring of downy mildew virulence is one of the efficient ways to assess genotypes. It allows to finding out genotypes resistance status in natural conditions

To cite this paper: Zoclanclounon, Y.A.B., G. Kanfany, C. Thiaw, A. Fofana, N. Mbaye and N. Cisse, 2018. Assessment of pearl millet genotypes for downy mildew resistance and agronomic performance under field conditions in senegal. Int. J. Agric. Biol., 20: 493-498 
(Wilson et al., 2008). The objective of this study was to evaluate pearl millet genotypes provided by ICRISAT for downy mildew resistance and yield in four agroecological zones of Senegal. Sources of resistance identified in this study can be used in pearl millet breeding program in Senegal.

\section{Materials and Methods}

\section{Plant Materials}

Plant materials provided by the Genetic Resources Division, ICRISAT (Patancheru, India) were composed of twenty genotypes including twelve downy mildew resistant differential lines, six improved varieties and two local checks (Souna 3 and IBMV8402) (Table 1).

\section{Experimental Set up}

Field evaluation was conducted during the rainy season 2015 (from $1^{\text {st }}$ July to $31^{\text {st }}$ October) at four locations, Bambey, Nioro, Kolda and Sinthiou Maleme corresponding respectively to North groundnut basin, South groundnut basin, Casamance and Oriental Senegal agro-ecological zones (Fig. 1). Genotypes were evaluated in each zone, in a randomized complete block design with two replications. Space between rows was $0.80 \mathrm{~m}$ and $0.40 \mathrm{~m}$ between plants within a row. Length of each row was $4.8 \mathrm{~m}$. A NPK (1515-15) fertilizer was applied before sowing at the rate of 150 $\mathrm{kg} \mathrm{ha}^{-1}$. Urea $\left(100 \mathrm{~kg} \mathrm{ha}^{-1}\right)$ was applied twice $(50 \%$ at 15 days after sowing and $50 \%$ at 30 days after sowing). Sprinkler irrigation was used as needed in order to maintain favourable relative humidity for pathogen development. The Fig. 2 presents the relative humidity and temperature of the four locations. Temperature globally varied from location to another with daily means of $28.59 \pm 1.74^{\circ} \mathrm{C}, 29.99 \pm 1.90^{\circ} \mathrm{C}$, $29.51 \pm 1.52^{\circ} \mathrm{C}, 31.60 \pm 2.24^{\circ} \mathrm{C}$ for Kolda, Bambey, Nioro and Sinthiou Maleme, respectively. High levels of humidity were recorded at Kolda ranging from $58 \%$ to $93 \%$. At Nioro, Bambey and Sinthiou Maleme, total means of daily relative humidity were respectively $77.79 \pm 8.52 \%$, $72.05 \pm 10.57 \%$ and $62.13 \pm 13.23 \%$.

\section{Data Collection}

Number of infected plants per plot was counted at 30 and 40 days after sowing. Genotypes were classified as described by Sharma et al., (2015) in different categories according to the following scale: resistant (downy mildew incidence $\leq$ $10 \%)$, moderately resistant $(10.1 \leq$ downy mildew incidence $\leq 20 \%)$, susceptible $(20.1 \leq$ downy mildew incidence $\leq 50 \%$ incidence) and highly susceptible (downy mildew incidence $>50 \%$ ). Number of diseased plants at 40 days after sowing was considered for incidence calculation because of augmentation of this number from 30 to 40 days after sowing. Days from sowing to $50 \%$ flowering (FLO), plant height (HEI), panicle length (LEN), panicle weight
(WEI), the number of productive panicles harvested (NPPH) and number of productive tillers (NPT) and yield (YIELD) were recorded.

\section{Data Analysis}

To examine the effect of genotype, location and their interaction on downy mildew incidence, analysis of variance was carried out based on the following Poisson regression model:

$\log \left(\frac{\text { Number of infected plants }}{\text { Total number of plants per plot }}\right)=\beta_{0}+\beta_{1}$ Genotype $+\beta_{2}$ Location
$\beta_{\mathrm{s}}$ are the parameters to be estimated from data. The generalized linear model (GLM) was used to fit the model with glm function of package stats (R Core Team, 2017). Relative variation was calculated as described by (Thakur et al., 2004) to evaluate genotypes resistance stability across agro-ecological areas. This parameter was computed in statistical program R 3.4 (R Core Team, 2017) using the following formula:

Relative variation $=\frac{\text { Standard deviation }}{\sqrt{\text { Mean of incidence }(100-\text { Mean of incidence })}}$

A principal component analysis was performed to describe agronomic data set (20 genotypes and 6 agronomic variables) using PCA function of FactoMineR package (Lê et al., 2008). In order to classify genotypes according to the agronomic traits, hierarchical clustering was performed on the first two components of the previous principal component analysis using HCPC function of FactoMineR package (Husson et al., 2010). Euclidean distance calculation and Ward clustering method were used.

\section{Results}

\section{Reaction of Pearl Millet Genotypes to Downy Mildew}

Significant differences among tested lines, locations and their interaction for downy mildew incidence were observed (Table 2). Differential responses to downy mildew between populations of the pathogen were observed in the tested lines. Differential downy mildew resistance lines IP22295 and IP22441 vary in their relative positions for downy mildew. IP22295 was susceptible at Kolda (incidence $=24.5 \%$ ) but resistant at Sinthiou Maleme, Bambey and Nioro. IP22441 was susceptible at Kolda (incidence $=30.5 \%$ ), resistant at Sinthiou Maleme (incidence $=6.5 \%$ ), moderately resistant at Bambey (incidence $=18 \%$ ) and highly susceptible at Nioro (incidence $=70 \%$ ). The international susceptible check $7042 \mathrm{~S}$ was highly susceptible in all the four locations Table 3. The improved varieties did not show variation in downy mildew responses. They were consistently resistant across locations. Downy mildew incidence was ranging from $0 \%$ to $91.12 \%$ across the tested locations 
Table 1: Pearl millet material used in this study

\begin{tabular}{llc}
\hline Line & Description & Country of origin \\
\hline 7042 DMS & Check & India \\
$852 B$ & DMR Differential line & India \\
IBMV8402 & Check & Senegal \\
ICMV-IS90309 & Improved variety & India \\
ICMV-IS90311 & Improved variety & India \\
ICMV-IS92326 & Improved variety & India \\
IP22291 & DMR Differential line & India \\
IP22295 & DMR Differential line & India \\
IP22313 & DMR Differential line & India \\
IP22315 & DMR Differential line & India \\
IP22319 & DMR Differential line & India \\
IP22439 & DMR Differential line & India \\
IP22441 & Improved variety & India \\
IP22442 & DMR Differential line & India \\
IP22445 & DMR Differential line & India \\
IP22446 & DMR Differential line & India \\
IP5082 & DMR Differential line & India \\
SOSAT-C88_Patancheru & Improved variety & India \\
SOSAT-C88_Sadore & Improved variety & India \\
Souna3 & Check & Senegal \\
\hline
\end{tabular}

*DMR: Downy mildew resistant

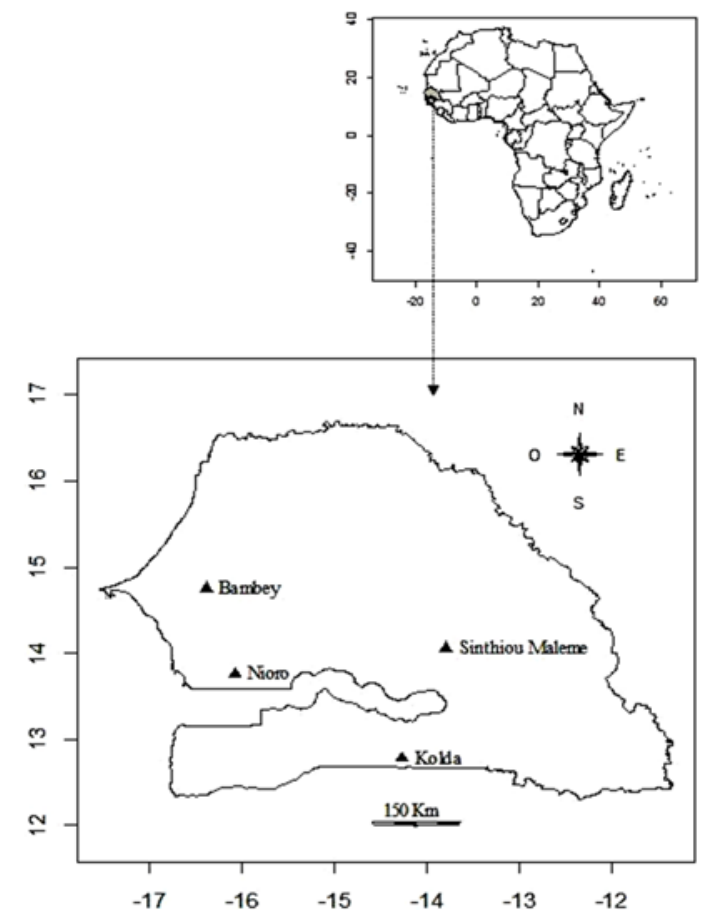

Fig. 1: Map showing the different surveyed sites

(Table 4). Significant difference of incidence mean $(\mathrm{p}<0.001)$ between $852 \mathrm{~B}$ and IP22441 was noted with $4.25 \%$ and $31.25 \%$ respectively (Table 4 ). Across locations, the highest incidence $(91.12 \%)$ was observed for $7042 \mathrm{~S}$ and the lowest ( $0 \%$ ) for IP22445, IP22442 and ICMV-IS92326 (Table 4). Relative variation analysis revealed that outside of genotypes with 0 as relative variation, IP22315, IP2295, SOSAT-C88-Sadore, SOSAT-C88-Pantacheru and local check Souna 3 presented stable resistance to downy mildew across the tested locations (Table 4).

\section{Agronomic Performance of Pearl Millet Genotypes}

Mean values of the agronomic traits of the tested genotypes in the four locations were presented in Table 5. Number of days from sowing to $50 \%$ flowering ranged from 44 days after sowing (IP22442) to 58 days after sowing (IP5082). Highest plant height and panicle length were respectively recorded for IP22313 $(168.53 \mathrm{~cm})$ and Souna $3(36 \mathrm{~cm})$ genotypes. SOSAT-C88_Patancheru produced the highest yield $\left(3.766 \mathrm{t} \mathrm{ha}^{-1}\right)$ followed by ICMV-IS 90311 (3.581 tha $\left.{ }^{-1}\right)$, SOSAT-C88_Sadore (3.325 t ha-1), ICMVIS $90309\left(3.251 \mathrm{t} \mathrm{ha}^{-1}\right)$, Souna $3\left(3.138 \mathrm{t} \mathrm{ha}^{-1}\right)$ and IBMV $8402\left(3.072 \mathrm{t} \mathrm{ha}^{-1}\right)$.

Principal component analysis was performed to identify discriminating agronomic traits according to 6 active variables (days from sowing to $50 \%$ flowering, plant height, panicle length, yield, the number of productive panicles harvested and number of productive tillers and 1 supplementary variable, downy mildew incidence recorded 40 days after sowing. Factorial axis 1 described $56 \%$ of overall variability (Fig. 3). Agronomic variables highly correlated to axis F1 were yield $(\mathrm{r}=0.91$, $\mathrm{p}<0.01)$, plant height $(\mathrm{r}=0.86, \mathrm{p}<0.01)$, number of productive panicles $(\mathrm{r}=0.85, \mathrm{p}<0.01)$, number of productive tillers $(\mathrm{r}=0.77, \mathrm{p}<0.01)$ and panicle length $(\mathrm{r}=$ $0.65, \mathrm{p}<0.01$ ).

Second factorial axis explained $19.16 \%$ of overall variability. It was correlated with days to $50 \%$ flowering $(\mathrm{r}=0.84, \mathrm{p}<0.01)$. Hierarchical ascendant clustering performed on factorial plan (axis 1, axis 2) revealed four clusters (Fig. 4). Cluster 1 contained three downy mildew susceptible genotypes (7042DMS, IP22295 and IP22315), characterized by low seed yield (v-test $=-2.5976, \mathrm{p}<$ 0.001 ). Cluster 2 is composed of six early maturing genotypes, resistant to downy mildew whereas cluster 3 grouped two extra-early and downy mildew susceptible genotypes. Nine genotypes with high yield (v-test $=3.5326$, $\mathrm{p}<0.001)$ and green fodder (v-test $=3.9232, \mathrm{p}<0.001)$ belonged to the cluster 4 (Fig. 4).

\section{Discussion}

The present study revealed variation in downy mildew incidence among the tested pearl millet genotypes. This variation can be due to intra-genetic variability of the tested plant materials. The variation in the responses of some genotypes to downy mildew across locations was also highlighted, suggesting that different populations of $S$. graminicola might be present in the various locations where the trials were conducted. IP22295 was susceptible at Kolda but resistant at Bambey, Nioro and Sinthiou Maleme. Furthermore, IP22441 was susceptible at Kolda, resistant at Sinthiou Maleme, moderately resistant at Bambey and highly susceptible at Nioro. This downy mildew variability across locations can be due to pathogenic variation of $S$. graminicola populations. 
Table 2: Analysis of deviance table of fitted model

\begin{tabular}{llllll}
\hline Source of variation & Df & Deviance Residual & Df Residual & Deviance & p ( Chi) \\
\hline Genotype & 19 & 3647.1 & 140 & 916.8 & $<2.2 .10^{-16}$ \\
Location & 3 & 42.3 & 137 & 874.5 & 0.002479 \\
Genotype $\times$ Location & 57 & 558.6 & 80 & 315.9 & $4.039 .10^{-16}$ \\
\hline
\end{tabular}

$* * \mathrm{p}<0.01 ; * * * \mathrm{p}<0.001$

Df: degree of freedom

Table 3: Reaction of genotypes to downy mildew in Bambey, Nioro, Kolda and Sinthiou Maleme

\begin{tabular}{|c|c|c|c|c|c|c|c|c|c|}
\hline \multirow[t]{2}{*}{ Genotypes } & \multicolumn{2}{|c|}{ Bambey } & \multicolumn{2}{|r|}{ Nioro } & \multicolumn{2}{|c|}{ Sinthiou } & \multicolumn{2}{|c|}{ Kolda } & \multirow[b]{2}{*}{ Mean } \\
\hline & DMI & Sensibility & DMI & Sensibility & DMI & Sensibility & DMI & Sensibility & \\
\hline $7042 \mathrm{~S}$ & 91 & $\mathrm{HS}$ & 100 & $\mathrm{HS}$ & 73.5 & $\mathrm{HS}$ & 100 & $\mathrm{HS}$ & 91.12 \\
\hline 852B & 3.5 & $\mathrm{R}$ & 0 & $\mathrm{R}$ & 8 & $\mathrm{R}$ & 5.5 & $\mathrm{R}$ & 4.25 \\
\hline ICMV-IS 90309 & 0 & $\mathrm{R}$ & 3 & $\mathrm{R}$ & 0 & $\mathrm{R}$ & 0 & $\mathrm{R}$ & 0.75 \\
\hline ICMV-IS 90311 & 0 & $\mathrm{R}$ & 0 & $\mathrm{R}$ & 2 & $\mathrm{R}$ & 2 & $\mathrm{R}$ & 1 \\
\hline ICMV-IS 92326 & 0 & $\mathrm{R}$ & 0 & $\mathrm{R}$ & 0 & $\mathrm{R}$ & 0 & $\mathrm{R}$ & 0 \\
\hline IP22291 & 2.5 & $\mathrm{R}$ & 0 & $\mathrm{R}$ & 0 & $\mathrm{R}$ & 0 & $\mathrm{R}$ & 0.62 \\
\hline IP22295 & 3.5 & $\mathrm{R}$ & 0 & $\mathrm{R}$ & 0 & $\mathrm{R}$ & 24.5 & $\mathrm{~S}$ & 7 \\
\hline IP22313 & 0 & $\mathrm{R}$ & 0 & $\mathrm{R}$ & 0 & $\mathrm{R}$ & 0 & $\mathrm{R}$ & 0 \\
\hline IP22315 & 12.5 & MR & 0 & $\mathrm{R}$ & 0 & $\mathrm{R}$ & 0 & $\mathrm{R}$ & 3.12 \\
\hline IP22319 & 7 & $\mathrm{R}$ & 0 & $\mathrm{R}$ & 0 & $\mathrm{R}$ & 5.5 & $\mathrm{R}$ & 3.12 \\
\hline IP22439 & 0 & $\mathrm{R}$ & 0 & $\mathrm{R}$ & 5 & $\mathrm{R}$ & 10 & $\mathrm{R}$ & 3.75 \\
\hline IP22441 & 18 & MR & 70 & HS & 6.5 & $\mathrm{R}$ & 30.5 & $\mathrm{~S}$ & 31.25 \\
\hline IP22442 & 0 & $\mathrm{R}$ & 0 & $\mathrm{R}$ & 0 & $\mathrm{R}$ & 0 & $\mathrm{R}$ & 0 \\
\hline IP22445 & 0 & $\mathrm{R}$ & 0 & $\mathrm{R}$ & 0 & $\mathrm{R}$ & 0 & $\mathrm{R}$ & 0 \\
\hline IP5082 & 0 & $\mathrm{R}$ & 0 & $\mathrm{R}$ & 0 & $\mathrm{R}$ & 2 & $\mathrm{R}$ & 0.5 \\
\hline SOSAT-C88-Sadore & 2 & $\mathrm{R}$ & 2.5 & $\mathrm{R}$ & 2 & $\mathrm{R}$ & 9.5 & $\mathrm{R}$ & 4 \\
\hline SOSAT-C88-Pantacheru & 2 & $\mathrm{R}$ & 7 & $\mathrm{R}$ & 6.5 & $\mathrm{R}$ & 3.5 & $\mathrm{R}$ & 4.75 \\
\hline Souna 3 & 10.5 & MR & 0 & $\mathrm{R}$ & 14.5 & MR & 9 & $\mathrm{R}$ & 8.5 \\
\hline Mean & 7.73 & & 9.13 & & 6.33 & & 10.25 & & \\
\hline
\end{tabular}

R: Resistant (Downy mildew incidence $\leq 10 \%$, HS: Highly susceptible (Downy mildew incidence $>50 \%$, MR: Moderately resistant $(10.1 \% \leq$ Downy mildew incidence $\leq 20 \%)$ and S: Susceptible $(20.1 \% \leq$ Downy mildew incidence $\leq 50 \%)$, DMI: Downy mildew incidence
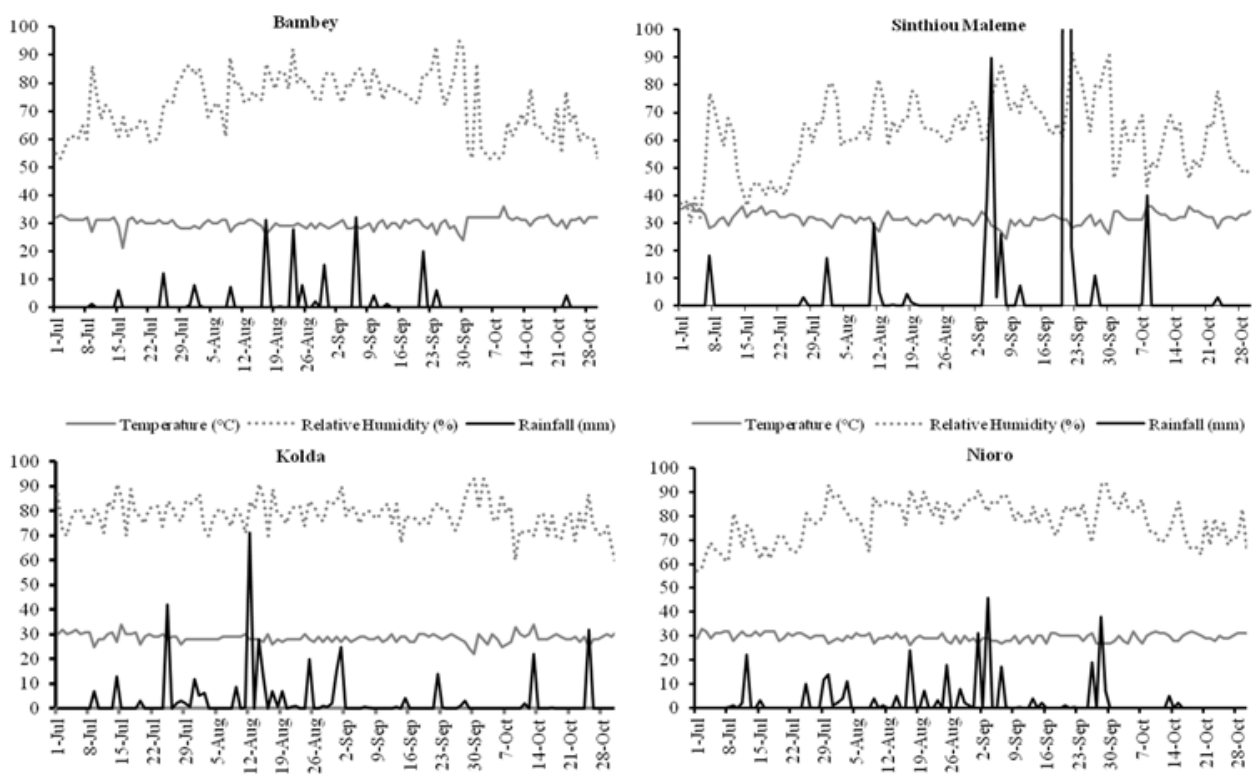

Fig. 2: Daily relative humidity and temperature at Kolda, Bambey Nioro and Sinthiou Maleme during rainy season 2015

Pathogen variability has already been proved through many studies using on-farm assessment (Sharma et al., 2007, 2011), isolates virulence under greenhouse conditions (Thakur et al., 2004; Pushpavathi et al., 2006) and DNA markers (Sastry et al., 1995; Sharma et al., 2010).

Our study revealed that the highest downy mildew incidence was observed at Kolda. It can be due to climatic difference between locations. In our study, the 
Table 4: Mean of downy mildew incidence at four locations and relative variation

\begin{tabular}{llll}
\hline Genotypes & $\begin{array}{l}\text { Downy mildew } \\
\text { incidence mean }\end{array}$ & Sensibility & $\begin{array}{l}\text { Relative } \\
\text { variation }\end{array}$ \\
\hline $7042 \mathrm{~S}$ & $91.12 \mathrm{a}$ & $\mathrm{HS}$ & 0.45 \\
$852 \mathrm{~B}$ & $4.25 \mathrm{~d}$ & $\mathrm{R}$ & 0.24 \\
IBMV8402 & $2.12 \mathrm{efg}$ & $\mathrm{R}$ & 0.19 \\
ICMV-IS90309 & $0.75 \mathrm{gh}$ & $\mathrm{R}$ & 0.00 \\
ICMV-IS90311 & $1.00 \mathrm{gh}$ & $\mathrm{R}$ & 0.00 \\
ICMV-IS92326 & $0.00 \mathrm{~h}$ & $\mathrm{R}$ & - \\
IP22291 & $0.62 \mathrm{gh}$ & $\mathrm{R}$ & 0.45 \\
IP22295 & $7.00 \mathrm{c}$ & $\mathrm{R}$ & 0.19 \\
IP22313 & $0.00 \mathrm{~h}$ & $\mathrm{R}$ & - \\
IP22315 & $3.12 \mathrm{def}$ & $\mathrm{R}$ & 0.04 \\
IP22319 & $3.12 \mathrm{def}$ & $\mathrm{R}$ & 0.24 \\
IP22439 & $3.75 \mathrm{de}$ & $\mathrm{R}$ & 0.00 \\
IP22441 & $31.25 \mathrm{~b}$ & $\mathrm{~S}$ & 0.39 \\
IP22442 & $0.00 \mathrm{~h}$ & $\mathrm{R}$ & - \\
IP22445 & $0.00 \mathrm{~h}$ & $\mathrm{R}$ & - \\
IP22446 & $1.25 \mathrm{fgh}$ & $\mathrm{R}$ & 0.00 \\
IP5082 & $0.50 \mathrm{gh}$ & $\mathrm{R}$ & 0.00 \\
SOSAT-C88-Pantacheru & $4.75 \mathrm{~d}$ & $\mathrm{R}$ & 0.14 \\
SOSAT-C88-Sadore & $4.00 \mathrm{de}$ & $\mathrm{R}$ & 0.13 \\
Souna3 & $8.50 \mathrm{c}$ & $\mathrm{R}$ & 0.17 \\
\hline R: Resistant (Downy mildew incidence $\leq 10 \%, \mathrm{HS}:$ Highly & susceptible \\
(Downy mildew incidence $>50 \%$, S: Susceptible $(20.1 \%$ & $\leq$ Downy \\
mildew incidence $\leq 50)$ & &
\end{tabular}

highest relative humidity was observed at Kolda. Kumar et al. (2012) explained that with $85-90 \%$ of relative humidity and temperature of $20-30^{\circ} \mathrm{C}$, downy mildew development is important. Environmental factors as weather and wind also influence spread of inoculum (Thakur et al., 2011).

Clustering revealed diversity in the tested lines according to downy mildew sensibility, seed yield and green fodder potentials and number of flowering day. Most of pearl millet lines possess desirable agronomic traits. Breeding lines have been generally found to be morphologically, genetically, and geographically quite diverse (Hu et al., 2015; Sehgal et al., 2015).

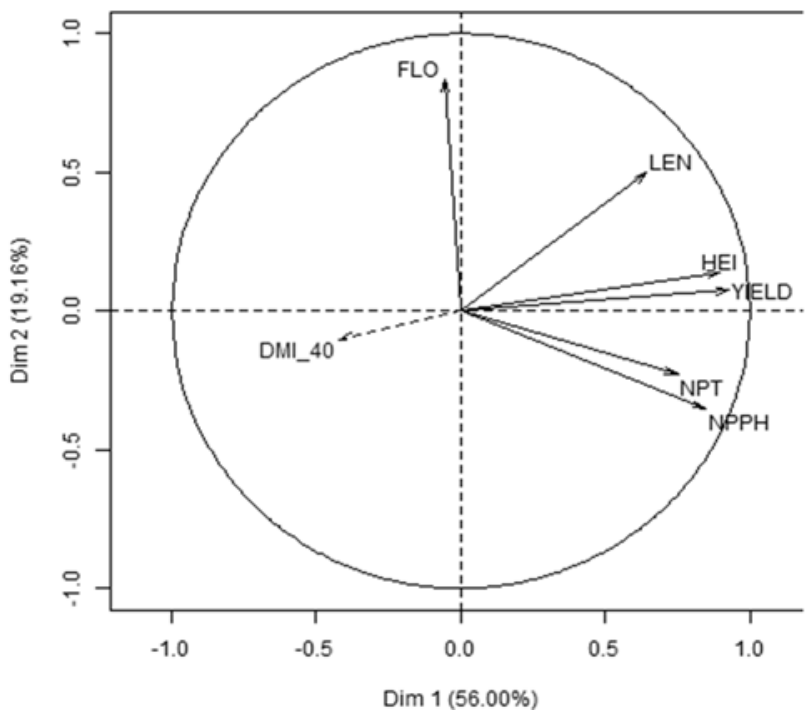

Fig. 3: Variables factor map

FLO: Days from sowing to $50 \%$ flowering, HEI: plant height, LEN: panicle length, WEI: panicle weight, NPPH: the number of productive panicles harvested, NPT: number of productive tillers, DMI_40: Downy mildew incidence recorded 40 days after sowing

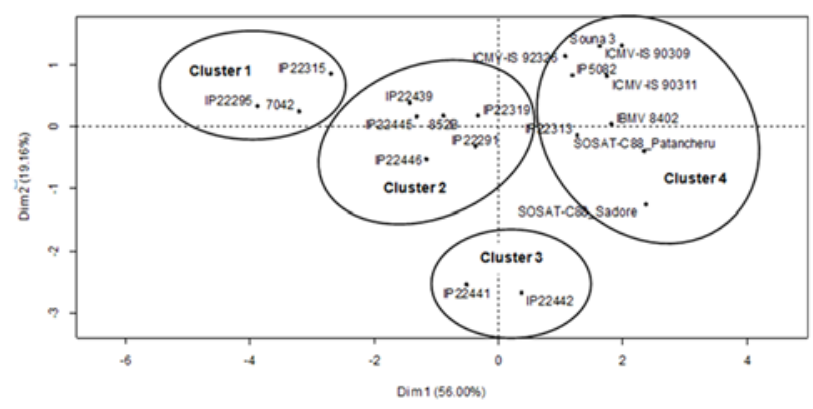

Fig. 4: Hierarchical ascendant classification analysis of the tested genotypes

Table 5: Mean values of agronomic traits across four locations

\begin{tabular}{llllllll}
\hline Genotypes & FLO (days) & HEI $(\mathrm{cm})$ & LEN $(\mathrm{cm})$ & NPT & NPPH & WEI (g) & Yield (tha $\left.{ }^{-1}\right)$ \\
\hline 7042S & $53.62^{*}$ & 105.85 & 14.12 & 10.62 & 38.12 & 0.39 & 1.03 \\
852B & 55.62 & 102.3 & 21.25 & 16.75 & 79.25 & 0.49 & 1.27 \\
IBMV 8402 & 53.62 & 144.41 & 27.12 & 18.25 & 98.5 & 1.17 & 3.07 \\
ICMV-IS 90309 & 56.87 & 142.01 & 29.37 & 18.87 & 77.75 & 1.24 & 3.25 \\
ICMV-IS 90311 & 55.75 & 141.11 & 27.37 & 17.87 & 87.87 & 1.37 & 3.58 \\
ICMV-IS 92326 & 54.87 & 158.28 & 31.5 & 19 & 64.25 & 0.75 & 1.96 \\
IP22291 & 54.37 & 101.4 & 18.5 & 17.12 & 80 & 0.91 & 2.37 \\
IP22295 & 53.87 & 72.78 & 16.75 & 12.5 & 27.5 & 0.15 \\
IP22313 & 55.62 & 168.53 & 18.87 & 17.87 & 104.87 & 0.80 & 0.40 \\
IP22315 & 57.37 & 75.45 & 17.87 & 14.12 & 51.87 & 0.38 & 0.99 \\
IP22319 & 57.5 & 117.9 & 15.87 & 19 & 78.12 & 0.69 & 1.81 \\
IP22439 & 57 & 93.87 & 17.62 & 15.75 & 73.62 & 0.55 & 1.45 \\
IP22441 & 49.12 & 95.57 & 12.87 & 21.25 & 81.37 & 0.59 & 1.55 \\
IP22442 & 44.37 & 124.08 & 22.37 & 15.62 & 100.37 & 0.79 & 2.07 \\
IP22445 & 55.5 & 89.4 & 19.62 & 18.25 & 58.62 & 0.54 & 1.42 \\
IP22446 & 53.5 & 110.05 & 16.12 & 15.75 & 73 & 0.60 & 1.57 \\
IP5082 & 58.25 & 145.45 & 22.12 & 17.75 & 98.87 & 1.01 & 2.64 \\
SOSAT-C88_Patancheru & 53.5 & 152.2 & 22.75 & 19.87 & 99.37 & 1.44 & 3.76 \\
SOSAT-C88_Sadore & 52.62 & 154.81 & 18.62 & 21.12 & 111.37 & 1.27 & 3.32 \\
Souna 3 & 54 & 160.05 & 36 & 16.75 & 79.25 & 1.20 \\
*Means with 8 replications (2 replications $\times 4$ locations),FLO: days to 50\% flowering, HEI: plant height, LEN: panicle length, WEI: panicle weight, NPPH: \\
number of productive panicles harvested, NPT: number of productive tillers & & & & 3.13 \\
\hline
\end{tabular}


Results of this study clearly highlighted the variability of downy mildew incidence among breeding lines and agroecological areas of Senegal. Furthermore, a pathogenic variability has been inferred across the different locations. Genotypes possessing desirable agronomic traits and showing stable resistance to downy mildew can be used in pearl millet breeding programs. Accurate identification of $S$. graminicola pathotypes present in Senegal by genetic tools should be explored as key issue for further study.

\section{Acknowledgements}

The authors like to thank ICRISAT for providing seed of pearl millet genotypes for the study.

\section{References}

Dangl, J.L. and J.D. Jones, 2001. Plant pathogens and integrated defence responses to infection. Nature, 411: 826-833

Das, I.K., 2017. Millet Diseases: Current Status and Their Management, In: Millets and Sorghum: Biology and Genetic Improvement, pp: 291322. Patil, J.V. (ed.). John Wiley \& Sons, Ltd, New York, USA

Diagne, J.P., N.Y.N. Seck and M.L. Paye, 2017. Bulletin Mensuel des Statistiques Economiques. Senegal. Available at http://www.ansd.sn/ressources/publications/ (Accessed 12 March 2017)

Hash, C.T., R.P. Thakur, V.P. Rao and A.B. Raj, 2006. Evidence for enhanced resistance to diverse isolates of pearl millet downy mildew through gene pyramiding. Int. Sorghum Millets Newslett., 47: 134 138

Hu, Z., B. Mbacké, R. Perumal, M.C. Guèye, O. Sy, S. Bouchet, P.V.V. Prasad and G.P. Morris, 2015. Population genomics of pearl millet (Pennisetum glaucum (L.) R. Br.): Comparative analysis of global accessions and Senegalese landraces. BMC Genom., 16: 1048-1060

Husson, F., J. Josse and P. Jérôme, 2010. Principal Component Methods Hierarchical Clustering - Partitional Clustering: Why Would We Need to Choose for Visualizing Data? Technical report AgroCampus, Applied Mathematics Department, France

Jukanti, A.K., C.L.L. Gowda, K.N. Rai, V.K. Manga and R.K. Bhatt, 2016. Crops that feed the world 11. Pearl Millet (Pennisetum glaucum L.): an important source of food security, nutrition and health in the arid and semi-arid tropics. Food Secur., 8: 307-329

Kumar, A., V.K. Manga, H.N. Gour and A.K. Purohit, 2012. Pearl millet downy mildew: challenges and prospects. Rev. Plant Pathol., 5: 139-177

Lê, S., J. Josse and F. Husson, 2008. FactoMineR: An R Package for Multivariate Analysis. J. Stat. Softw., 25: 1-18

Leonard, K.J., 1977. Selection pressures and plant pathogens. Ann. New York Acad. Sci., 287: 207-222

Pushpavathi, B., R.P. Thakur, K. Chandrashekara Rao and V.P. Rao, 2006. Characterization of Sclerospora graminicola isolates from pearl millet for virulence and genetic diversity. Plant Pathol. J., 22: 28-35
R Core Team, 2017. R: A Language and Environment for Statistical Computing. R Foundation for Statistical Computing, Vienna, Austria. URL https://www.R-project.org/

Sastry, J.G., W. Ramakrishna, S. Sivaramakrishnan, R.P. Thakur, V.S Gupta and P.K. Ranjekar, 1995. DNA fingerprinting detects genetic variability in the pearl millet downy mildew pathogen (Sclerospora graminicola). Theor. Appl. Genet., 91: 856-861

Sehgal, D., L. Skot, R. Singh, R.K. Srivastava, S.P. Das, J. Taunk, P.C. Sharma, R. Pal, B. Raj, C.T. Hash and R.S. Yadav, 2015. Exploring potential of pearl millet germplasm association panel for association mapping of drought tolerance traits. Available at: http://journals.plos.org/plosone/article?id=10.1371/journal.pone.012 2165 (Accessed: 22 March 2016)

Sharma, R., V.P. Rao, S. Senthilvel, SC. Rajput and R.P. Thakur, 2011. Virulence diversity in north Indian isolates of Sclerospora graminicola, the pearl millet downy mildew pathogen. J. Plant Pathol., 93: 71-78

Sharma, R., V.P. Rao, R.K. Varshney, V.P. Prasanth, S. Kannan and R.P. Thakur, 2010. Characterisation of pathogenic and molecular diversity in Sclerospora graminicola, the causal agent of pearl millet downy mildew. Arch. Phytopathol. Plant Prot., 43: 538-551

Sharma, R., H.D. Upadhyaya, S. Sharma, V.L. Gate and C. Raj, 2015. New sources of resistance to multiple pathotypes of in the pearl millet mini core germplasm collection. Crop Sci., 55: 1-10

Sharma, Y.K., S.K. Yadav, I.S. Khairwal, D. Bajri-chomu and D. Bajriosian, 2007. Evaluation of pearl millet germplasm lines against downy mildew incited by Sclerospora graminicola in western Rajasthan. SAT E-Journal ICRISAT, 3: 1-2

Siddaiah, C.N., N.R. Satyanarayana, V. Mudili, V.K. Gupta, S. Gurunathan, S. Rangappa, S.S. Huntrike and R.K. Srivastava, 2017. Elicitation of resistance and associated defense responses in Trichoderma hamatum induced protection against pearl millet downy mildew pathogen. Sci. Rep., 7: 43991

Sudisha, J., A. Kumar, K.N. Amruthesh, S.R. Niranjana and H.S. Shetty, 2011. Elicitation of resistance and defense related enzymes by raw cow milk and amino acids in pearl millet against downy mildew disease caused by Sclerospora graminicola. Crop Prot., 30: 794-801

Sudisha, J., S.A. Kumar, R.P. Thakur, V.P. Rao and H.S. Shetty, 2009. Molecular characterization of Sclerospora graminicola, the incitant of pearl millet downy mildew using ISSR markers. J. Phytopathol., 157: 748-755

Thakur, R.P., R. Sharma and V.P. Rao, 2011. Screening Techniques for Pearl Millet Diseases. Information Bulletin No. 89. International Crops Research Institute for the Semi-Arid Tropics, Patancheru, India

Thakur, R.P., V.P. Rao, B.M. Wu, K.V. Subbarao, H.S. Shetty, G. Singh, C. Lukose, M.S. Panwar, P. Sereme, D.E. Hess, S.C. Gupta, V.V Dattar, S. Panicker, N.B. Pawar, G.T. Bhangale and S.D. Panchbhai, 2004. Host resistance stability to downy mildew in pearl millet and pathogenic variability in Sclerospora graminicola. Crop Prot., 23 901-908

Wilson, J.P., M.D. Sanogo, S.K. Nutsugah, I. Angarawai, A. Fofana, H. Traore, I. Ahmadou and F.P. Muuka, 2008. Evaluation of pearl millet for yield and downy mildew resistance across seven countries in sub-Saharan Africa. Afr. J. Agric. Res., 3: 371-378

(Received 17 May 2017; Accepted 18 September 2017) 